\title{
MENILAI PENGELOLAAN ASPIRASI PUBLIK PADA MEDIA MASSA DI KALIMANTAN
}

\author{
Rustan A. \\ PKP2A III Lembaga Administrasi Negara \\ JI. H.M Ardans (Ring Road III) Samarinda-Kalimantan Timur \\ Email : rustanamarullah8@gmail.com
}

\begin{abstract}
The wide coverage of work and scope of public services requires the public participation to provide input or informationfor the regional government in order to optimize the performance of public service and regional development. Consequently, the media for channeling public aspirations need to be available. On the other hand the handling of the public's aspirations need to be managed well and solvethe needs of the public. This study attempted to assess the public's aspirations management model in a local newspaper in Kalimantan. This study is a descriptive study with a qualitative approach and the analysis tool appliedis content analysis. From the various models of complaints management that are shown in the local newspaper in Kalimantan, in general it can be concluded that model of the public aspirations' column that more interactive, two-way, communicative, and complemented by a follow-up solution is a better model in handling of complaints, thus needs to be developed or replicated by other local governments. In addition, the role of the mass media as a bridge of information and public communication to the government needs to be optimized continuously.
\end{abstract}

Keywords: Management of Public Aspirations, Newspaper, Kalimantan

\begin{abstract}
Abstrak
Luasnya wilayah kerja dan ruang lingkup pelayanan publik menuntut peran serta masyarakat dalam memberikan masukan ataupun informasi kepada pemerintah daerah agar kinerja pembangunan dapat lebih optimal. Oleh karena itu, media untuk menyalurkan aspirasi publik tersebut perlu tersedia. Di sisi lain penanganan atas aspirasi publik tersebut perlu dikelola secara baik dan menjawab kebutuhan publik. Kajian ini mencoba melakukan penilaian atas model pengelolaan aspirasi publik di surat kabar lokal yang ada di kalimantan. Kajian ini merupakan penelitian deskriptif dengan pendekatan kualitatif dengan alat analisis yang digunakan adalah analisis isi(content analysis). Dari berbagai model penanganan pengaduan masyarakat yang diperlihatkan pada surat kabar lokal di kalimantan, secara umum dapat diberikan penilaian bahwa model penanganan kolom aspirasi publik yang lebih interaktif, dua arah, komunikatif, dan disertai penjelasan langkah tindak lanjut adalah model penanganan pengaduan yang lebih baik dan perlu dikembangkan atau direplikasikan oleh pemerintah daerah lainnya. Selain itu, peran serta media massa sebagai
\end{abstract}

1 Naskah di terima pada 27 Februari 2015, revisi pertama pada 30 Mei 2015, disetujui pada 27 Juli 2015 
jembatan penghubung informasi dan komunikasi publik kepada pemerintahnya perlu semakin dioptimalkan.

Kata Kunci: Pengelolaan Aspirasi Publik, Surat Kabar, Kalimantan

\section{A. PENDAHULUAN}

Paradigma pembangunan daerah yang berpijak pada kebutuhan publik (design by public) saat ini sedang trend digalakkan. Semaraknya kegiatan 'blusukan', 'sidak', ataupun 'rembug warga' yang digelar oleh pengambil kebijakan menunjukkan bahwa pemerintah saat ini mencoba memanfaatkan berbagai saluran aspirasi publik dalam membenahi penyelenggaraan pemerintahannya. Tentu saja banyak pendapat yang kemudian mengatakan bahwa langkahlangkah tersebut sebagai wujud ketidakpercayaan pada sistem birokrasi yang ada. Oleh karena itu, esensi utama yang penting dilakukan adalah pembenahan mekanisme sistem pemerintahan birokrasi terutama pada upaya pengelolaan pengaduan atau aspirasi publik yang lebih optimal dan responsif. Jika sistem birokrasi tersebut telah mampu berjalan dengan optimal, tentu intensitas kegiatan 'blusukan', 'sidak', ataupun 'rembug warga' dapat dikurangi.

Berkaitan dengan hal tersebut, organisasi publik harus segera dapat bertransisi menuju pada organisasi pelayan publik yang responsif. Fokus dan orientasi organisasi pelayan publik sebaiknya tidak mengutamakan pada upaya memperbesar struktur organisasi, peningkatan penghasilan aparatur, atau pemenuhan sarana dan prasarana kantor semata, namun secara dominan pada upaya memenuhi kebutuhan publik (servant- organization), serta responsif dan aktif pada kritik publik. Publik sendiri secara valid memahami permasalahan disekitar lingkungan sosialnya, sehingga organisasi publik perlu menyandarkan informasinya pada publik, dan memanfaatkan informasi atau pengaduan publik tersebut untuk membenahi dan memantau kinerjanya. Pengelolaan pengaduan masyarakat oleh LAN (2006) disebutkan sebagai salah satu strategi untuk meningkatkan kualitas atau kinerja pelayanan publik, sebab unit pelayanan dapat mengetahui kelemahan-kelemahan dalam memberikan pelayanan dipandang dari kacamata pelanggan.

Pada dasarnya, telah cukup banyak sarana atau media pengaduan bagi publik yang disediakan oleh pemerintah daerah untuk mengutarakan masukan, kritik, maupun aspresiasinya kepada pemerintah daerahnya. Namun demikian, terkadang sarana atau media pengaduan tersebut tidak difungsikan sebagaimana mestinya atau hanya sekedar 'penampilan' saja tanpa pengelolaan yang optimal atau tindaklanjut yang berarti, padahal setiap aspirasi masyarakat yang masuk adalah sebuah nilai atau bentuk kepedulian publik kepada daerahnya. Masih banyaknya keluhan dan masukan masyarakat menjadi latar belakang perlunya Pemerintah hadir ditengah masyarakat. Men-PANRB, Yuddy Chrisnandi (2014) telah memberikan gambaran bahwa 
pengelolaan pengaduan masyarakat sejalan dengan nawa cita dari Kabinet Kerja Jokowi-JK, khususnya yang harus menghadirkan pemerintah di tengah masyarakat dalam bentuk pelayanan publik yang semakin baik.

Menpan-RB,Yuddy Chrisnandi (2014) juga mendorong masyarakat untuk berani mengadukan atau menyampaikan keluhannya apabila mendapatkan perlakuan yang tidak baik dalam pelayanan publik. Pengaduan itu dapat dilakukan kepada penyelenggara pelayanan publik, sesuai dengan kebijakan no wrong door policy, yakni menerima pengaduan dari manapun dan jenis apapun serta menjamin bahwa pengaduan akan disalurkan kepada penyelenggara pelayanan publik yang berwenang menangani. Hal itu sesuai dengan Permen PANRB nomor 24 tahun 2014 tentang Pedoman Penyelenggaraan Pengelolaan Pengaduan Pelayanan Publik Secara Nasional.

Hingga menjelang akhir 2014, Ombudsman menerima 6.180 pengaduan masyarakat. Dari jumlah itu $43,7 \%$ pengaduan terkait pemerintah daerah, terutama pemerintah kabupaten/kota. pemerintah daerahpaling banyak diadukan karena kerja-kerja pemerintah daerah banyak bersinggungan dengan masyarakat seperti pengurusan perizinan. Substansi yang dilaporkan paling banyak berkaitan dengan kepegawaian (16\%) seperti seleksi CPNS, mutasi, gaji atau honor, pemecatan dan sertifikasi guru. Disusul pertanahan $(12,9 \%)$ seperti ganti rugi tanah, pembuatan sertifikat, pengukuran, sertifikat ganda dan sengketa lahan. Berikutnya, soal pendidikan seperti Penerimaan Peserta Didik Baru
(PPDB), beasiswa, ujian nasional. kekerasan dan pungutan liar pendidikan. Terakhir, substansi paling banyak diadukan berkaitan dengan perhubungan dan infrastruktur di antaranya jalan rusak, sarana dan prasarana transportasi serta pungutan liar. Jenis mal-administrasi yang paling banyak diadukan bersinggungan dengan penundaan berlarut $(25,4 \%)$, penyimpangan prosedur $(20,3 \%)$, tidak memberikan pelayanan $(13,9 \%)$ dan penyalahgunaan wewenang $(11,7$ \%) (Santoso, 2014).

B a $p$ e $n$ a s $\left(\begin{array}{llll}2 & 0 & 1 & 0\end{array}\right)$ menyampaikan bahwa beberapa studi terdahulu menyatakan bahwa kondisi penanganan pengaduan atau manajemen pengaduan belum berjalan secara optimal dan dianggap belum efektif. Sebagian besar masyarakat belum memahami bahwa dalam pelayanan publik terdapat hak masyarakat untuk menyampaikan keluhan atau masukan atas pelayanan yang diterima. Sebuah studi menunjukkan bahwa selama ini masyarakat lebih mengandalkan media surat kabar (koran) sebagai media yang dinilai masih paling efektif untuk bisa menyampaikan berbagai keluhan, yaitu sebesar (53.8\%). Posisi ini diikuti oleh radio $(33.91 \%)$ dan pesan singkat (SMS) sebesar 30.65\%.

\section{Rumusan Masalah dan Tujuan Penelitian}

Sebagai media yang paling diandalkan publik, surat kabar juga telah menjadi wadah utama bagi pemerintah daerah dalam menampungkritik, masukan, maupun apresiasi warganya. Upaya menampung aspirasi publik tersebut dilakukan dengan menyediakan suatu 
kolom atau rubrik aspirasi publik melalui SMS center yang telah disediakan pemerintah daerah. Namun demikian, terdapat berbagai model kolom atau rubrik aspirasi publik tersebut, serta model pengelolaan atas kolom pengaduan publik tersebut yang berbeda-beda. Oleh karena itu, rumusan masalah pada kajian ini adalah bagaimana model pengelolaan aspirasi publik pada media surat kabar lokal yang terdapat di Kalimantan? dan model pengelolaan aspirasi publik terbaik seperti apa yang dapat diterapkan oleh pemerintah daerah?

Berangkat dari penjelasan tersebut di atas, kajian ini bertujuan untuk mencoba melakukan penilaian secara umum terhadap pengelolaan pengaduan atau aspirasi publik pada media surat kabar lokal yang terdapat di Kalimantan. Dari hasil penilaian tersebut, dapat direkomendasikan model pengelolaan pengaduan publik pada media massa (khususnya surat kabar) yang lebih efektif, responsif, dan menjawab kebutuhan publik sehingga dapat menjadi contoh baik (best model) bagi pemerintah daerah lainnya.

\section{B. METODE PENELITIAN}

Penelitian terhadap penanganan pengaduan masyarakat di surat kabar ini merupakan penelitian deskriptif dengan pendekatan kualitatif. Adapun alat analisis yang digunakan adalah analisis isi (content analysis), dimana peneliti berupaya memaknakan isi atau menarik kesimpulan secara sistematis dan objektif dari suatu bentuk pesan atau komunikasi (Berelson 1952; Holsti, 1968 dalam Lal Das \& Bhaskaran, 2008) yang ada pada media massa. Secara umum, penelitian ini membatasi lingkupnya pada upaya menggambarkan model terbaik penanganan aspirasi publik serta respon dari pemerintah daerah yang ditampilkan dalam surat kabar lokal.

Data dan informasi yang digunakan berupa kolom/ rubrik aspirasi publik yang disediakan oleh pemerintah daerah pada surat kabar lokal. Media massa lokal yang dipilih adalah salah satu harian terbesar di Provinsi Kalimantan Timur (Kaltim Post), Provinsi Kalimantan Selatan (Banjarmasin Post), dan Provinsi Kalimantan Barat (Tribun Pontianak). Adapun Harian Kalteng post yang merupakan salah satu harian terbesar di Kalimantan Tengah telah dipantau penulis selama januari-februari Tahun 2015, namun kolom/ rubrik aspirasi publik sebagai sarana pengaduan masyarakat tidak tersedia pada harian tersebut. Sehingga tidak dapat dianalisis lebih lanjut bagaimana mekanisme penanganan pengaduan masyarakat oleh pemerintah daerah di Kalimantan Tengah. Adapun sampel yang digunakan dalam kajian ini dipilih secara purposive sampling meliputi, Kota Balikpapan, Kabupaten Paser, Kota Bontang, Kabupaten Kutai Kartanegara, Kota Pontianak, dan khusus Kalimantan Selatan secara umum, karena kolom atau rubrik aspirasi yang ditampilkan relatif berbeda dengan daerah lainnya.

Kolom Aspirasi Publik atau SMS Pembaca atau dulu dikenal dengan Rubrik Surat Pembaca menjadi fokus penelitian karena merupakan mimbar bebas bagi pembaca untuk berekspresi menyampaikan aspirasinya. Para penulis Kolom Aspirasi Publik tersebut tidak sematamata menulis tanpa alasan. Para penulis 
merupakan warga atau satu kelompok yang berani mengungkapkan pikirannya atas dasar kenyataankenyataan sosial yang mereka temui dalam kehidupan sehari-hari. Melalui Kolom Aspirasi Publik/Surat Pembaca sebuah organisasi, lembaga, individual atau suatu kelompok dapat memantau keadaan sekelilingnya, sehingga peristiwa-peristiwa atau kenyataankenyataan yang tidak sesuai dengan aturannya dan dirasakan janggal dapat dikemukakan hingga menjadi lebih jelas (Setianti, dkk., 2007:9). Menurut Abdullah dalam Setianti, dkk (2007:12), Kolom Aspirasi Publik/ Surat Pembaca memiliki kekuatan tersendiri dalam membentuk opini khalayak. Karena mampu mempengaruhi opini khalayak banyak pembaca yang memanfaatkan Kolom Aspirasi Publik/Surat Pembaca untuk menyampaikan keluhan atau protes dan ketidakpuasan ataupun informasi lain yang biasanya berupa unek-unek dari jeleknya pelayanan suatu lembaga.

Public relations pemerintah yang baik tidak menganggap remeh Kolom Aspirasi Publik/Surat Pembaca sebab Kolom Aspirasi Publik/Surat Pembaca bisa mempengaruhi kredibilitas lembaga atau individu. Public relations dapat memanfaatkan surat kabar ataupun media cetak lainnya untuk mengetahui opini publik, dan keluhan-keluhan dari publiknya melalui rubrik surat pembaca, kemudian dapat memberikan tanggapan terhadap pernyataanpernyataan yang diungkapkan oleh masyarakatnya. Sehingga berita, feature, artikel dan surat pembaca dapat merupakan umpan balik dari suatu proses komunikasi antara publik dan PR suatu lembaga dan hal ini merupakan salah satu bentuk publisitas (Setianti, dkk., 2007:14)

\section{KERANGKA TEORITIS DAN KEBIJAKAN \\ Pelayanan Publik dan Pengelolaan Pengaduan Masyarakat}

UU No. 25 Tahun 2009 Tentang

Pelayanan Publik secara umum mendefinisikan pelayanan publik sebagai kegiatan atau rangkaian kegiatan dalam rangka pemenuhan kebutuhan pelayanan sesuai dengan peraturan perundang-undangan bagi setiap warga negara dan penduduk atas barang, jasa, dan/atau pelayanan administratif yang disediakan oleh penyelenggara pelayanan publik. Untuk menjalankan kegiatan tersebut secara optimal, perlu dipenuhi tiga hal penting berikut (Lenvine dalam PKP2AILAN, 2008) :

1. Responsiveness, yaitu daya tanggap penyedia layanan terhadap harapan, keinginan, aspirasi, maupun tuntutan pengguna layanan.

2. Responsibility, yaitu suatu ukuran yang menunjukkan seberapa jauh proses pemberian layanan publik itu dilakukan sesuai dengan prinsipprinsip atau ketentuan-ketentuan administrasi dan organisasi yang benar dan telah ditetapkan.

3. Accountability, yaitu suatu ukuran yang menunjukkan seberapa besar proses penyelenggaraan pelayanan sesuai dengan kepentingan stakeholders dan norma-norma yang ada dalam masyarakat.

Terkait dengan responsivitas, posisi strategis pemerintah daerah sebagai ujung tombak penyedia layanan publik dikemukakan oleh Rayner (1997) dalam Purwanto 
(2008:190) yaitu salah satu fungsi penting yang harus dijalankan oleh pemerintah daerah adalah menjadi forum dimana masyarakat dapat menegosiasikan apa yang menjadi kepentingan mereka, menyampaikan rasa keprihatinan mengenai masalahmasalah yang mengganggu mereka dan mencari konsensus atau mengakomodasi kepentingan orang lain.

Wah (2011) dalam penelitiannya telah merumuskan inovasi yang timbul dari penanganan pengaduan, bahwa "All public agencies should address complaints accordingly and view them as a source of innovation. Efficient and effective complaints management has a positive impact on people and enhances image of the Government. The ability of agencies to deal with complaints systematically and effectively will ensure quality improvement in public service delivery. Public complaints provide the source of grievances with ample opportunities for innovation. The ability to innovate from public complaints is the ability to adapt to an altered environment, to learn, and to evolve for the benefit of the public as well as to enhance national competitiveness".

Perpres No. 76 Tahun 2013 Tentang Pengelolaan Pengaduan Pelayanan Publik menyebutkan bahwa penyelenggara pelayanan publik wajib menyediakan sarana pengaduan dan menugaskan pelaksana yang kompeten dalam pengelolaan pengaduan. Bahwa pembentukan sarana pengaduan dan penugasan kepada pengelola pengaduan pelayanan publik bertujuan untuk memenuhi kebutuhan masyarakat dalam memperoleh pelayanan publik yang berkualitas, wajar, dan adil. Selain itu, salah satu kewajiban penyelenggara adalah menerima, menanggapi, memproses, dan menyelesaikan setiap pengaduan. Pengelolaan pengaduan atau aspirasi publik ini urgen dilaksanakan dalam menjembatani keinginan publik kepada pemerintah atau penyelenggara pelayanan publik, sebab masyarakat memiliki hak untuk mendapat pelayanan yang berkualitas sesuai dengan asas dan tujuan pelayanan, mendapat tanggapan terhadap pengaduan yang diajukan, serta mengadukan pelaksana/penyelenggara yang melakukan penyimpangan standar pelayanan dan/atau tidak memperbaiki pelayanan.

Untuk mewujudkan keinginan publik tersebut, peran serta masyarakat sangat dibutuhkan dalam proses pembuatan suatu keputusan tentang proyek, program ataupun kebijakan. Hal ini mengingat bahwa masyarakatlah yang akan merasakan dampak dari suatu proyek maupun kebijakan. Oleh sebab itu kontribusi masyarakat sangat diperlukan dalam upaya perencanaan suatu kebijakan. Hadi (1999) menyebutkan bahwa masyarakat adalah "local expert" tentang lingkungan disekitarnya, sehingga layak didengar pendapat dan gagasannya agar program dan proyek yang akan dilakukan workable. Di samping itu keberlanjutan dari proyek, program dan kebijakan akan terjamin jika masyarakat diikutsertakan (Kurniawan, 2006:35).

Hal senada disampaikan oleh Denhardt dan Denhardt (2003) dalam Purwanto (2008:187) yang menyebutkan bahwa melalui partisipasi publik yang luas dalam proses pembuatan kebijakan maka 
warga negara dapat membantu meningkatkan jaminan atau kepastian bahwa suara dan kepentingan individu maupun kelompok-kelompok yang ada dalam masyarakat didengarkan dan kemudian direspon oleh pemerintah secara adil.

Dalam penjelasan PP No. 96 Tahun 2012 Tentang Pelaksanaan UU No. 25 Tahun 2009 Tentang Pelayanan Publik dijelaskan bahwa peran serta masyarakat dalam penyelenggaraan pelayanan publik diperlukan untuk menjamin pelayanan publik dilaksanakan secara transparan dan akuntabel serta sesuai dengan kebutuhan dan harapan Masyarakat. Peran serta masyarakat tidak hanya dalam bentuk peran serta secara aktif dalam penyusunan standar pelayanan, tetapi juga sampai dengan pengawasan dan evaluasi penerapan standar, evaluasi kinerja dan pemberian penghargaan, serta penyusunan kebijakan pelayanan publik.

Blind (2007) dalam Dwiyanto (2011) mengatakan bahwa dalam perspektif politik, kepercayaan terjadi ketika warga menilai lembaga pemerintah dan para pemimpinnya dapat memenuhi janji, efisien, adil, dan jujur. Jika institusi pemerintah, pejabat publik, dan kebijakan yang dibuatnya dinilai baik oleh warga maka warga akan memiliki kepercayaan yang tinggi terhadap pemerintah. Tingginya kepercayaan publik menunjukkan warga merasa senang, nyaman, serta mendukung pemerintah dan kebijakannya. Pengalaman berhubungan dengan institusi pemerintah berpengaruh terhadap proses pembentukan kepercayaan pada institusi tersebut. ketika warga berhubungan dengan institusi pemerintah tertentu dan menilai bahwa institusi itu dan para pejabatnya bersifat terbuka, mudah diakses informasinya, dan sering melibatkan warga dalam mengambil keputusan maka pengalaman tersebut akan membentuk kepercayaannya terhadap pemerintah (Dwiyanto, 2011:355-366) Taleghani, dkk (2011) dalam penelitiannya menyebutkan bahwa "Organizations should emphasize the importance of identifying customer complaint factors and complaint intentions that crucially determine their business success. With respect to those who consider that complaints are worthless and have no gain, management should consider enhancing mutual communication between service personnel and customers. Therefore, excellent service is a genuine key for a better future, for both customers and suppliers (Day, 2004). However, this can only be achieved with a profound knowledge of evolving customer needs". Oleh karena itu, kemampuan pemerintah daerah untuk mengelola dan mengidentifikasi aspirasi publik yang valid, reliable, nyata, dan mempunyai pengaruh penting bagi publik sekitarnya sangat penting untuk dilakukan serta ditindaklanjuti. Selain itu, kemampuan aparatur memberikan pelayanan prima atas setiap pengaduan publik akan mendorong publik secara aktif membangun daerahnya.

\section{Peran Media Massa dalam Mendorong Kebijakan Publik Unggul}

Media massa merupakan satu instrumen penting dalam proses kebijakan publik. Media massa dalam sejarahnya menjadi faktor kunci yang 
berpengaruh besar dalam membangun opini publik dalam perumusan kebijakan. Media telah mampu mamposisikan dirinya sebagai elemen mendasar untuk membangun konstruksi sosial, terutama dalam pembuatan agenda kebijakan. Parsons ( 20005$)$ dalam Nuh (2010) mengkonstruksikan media massa dari berbagai pendapat sebagai aspek kunci dari proses "labelling" terhadap problem sosial, dari yang bersifat kecil menjadi problem yang besar. Media memberikan dampak pada penambahan "sensitivitas" dan "memperkuat" sesuatu yang dilabeli problem. Dari konstruksi peranan media yang demikian, Parsons mengatakan bahwa media massa dapat membentuk konteks untuk respons kebijakan, dan mempengaruhi "opini publik" dengan menentukan agenda publik dari sudut pandang insiden atau peristiwa (Nuh, 2010:228).

Penelitian yang dilakukan oleh Livingstone and Markham (2008) menyimpulkan bahwa, "civic participation is, to a moderate degree, influenced by media use. While such influence appears to differ for different media and for different forms of participation, there is more evidence to suggest that media use enhances than undermines participation. However, media use appears to play the greatest role is sustaining political interest, being irrelevant to or even negative in relation to taking action"

Berdasarkan UU No. 40 Tahun 1999 Tentang Pers disebutkan bahwa pers yang juga melaksanakan kontrol sosial sangat penting pula untuk mencegah terjadinya penyalahgunaan kekuasaan baik korupsi, kolusi, nepotisme, maupun penyelewengan dan penyimpangan lainnya. Terkait hal tersebut, optimalisasi peranan pers yang cukup strategis perlu semakin diperkokoh diantaranya, memenuhi hak masyarakat untuk mengetahui; menegakkan nilai-nilai dasar demokrasi, mendorong terwujudnya supremasi hukum, dan hak asasi manusia, serta menghormat kebhinekaan; mengembangkan pendapat umum berdasarkan informasi yang tepat, akurat dan benar; melakukan pengawasan, kritik, koreksi, dan saran terhadap hal-hal yang berkaitan dengan kepentingan umum; serta memperjuangkan keadilan dan kebenaran.

Media tidak hanya sekedar penyebar informasi. Media memiliki sejumlah tanggung jawab ikut aktif melibatkan diri dalam interaksi sosial dan kadangkala menunjukkan arah atau memimpin, serta berperanserta dalam menciptakan hubungan dan integrasi. Dalam masyarakat, media bergerak dengan ditandai oleh adanya penyebaran kekuasaan, yang diberikan kepada individu, kelompok, dan kelas sosial secara tidak merata. Selain itu, kehadiran media dalam kaitannya dengan kebijakan menjadi sangat penting. Salah satu unsur penting dari media yang makin bebas dan kaitannya dengan penyelenggaraan pemerintahan yang baik adalah tersedianya informasi yang terbuka bagi masyarakat untuk menunjukkan kinerja macam apa yang ditunjukkan oleh para pejabat dalam menjalankan mandat mereka sebagai pemerintah lokal (Kurniawan, 2006:30).

Masyarakat sering memperoleh informasi tentang berbagai hal yang terkait dengan pelayanan publik melalui media massa. Informasi yang 
mereka perolah dari media massa tentang kemampuan pemerintah dalam menyelenggarakan pelayanan publik juga dapat membentuk persepsi mereka tentang institusi pemerintah dan para pejabatnya. Hal itu menjelaskan mengapa institusi pemerintah dan para pejabatnya semakin sering membeli slot iklan di media cetak maupun audio visual untuk menunjukkan kinerja terutama pada saat menjelang pemilu (Dwiyanto,2011:364).

Salah satu media yang sering digunakan dalam membentuk persepsi realitas sebagaimana disebutkan di atas adalah surat kabar. Surat kabar telah lama dipergunakan untuk penyebaran informasi. Sejalan dengan berjalannya waktu, surat kabar tidak hanya berfungsi sebagai alat informasi saja, tetapi banyak fungsi yang dapat diberikan oleh surat kabar. Suwardi (1993) dalam Kurniawan (2006:14) menjelaskan bahwa fungsi-fungsi dari surat kabar adalah sebagai berikut :

a. Fungsi menyiarkan informasi, berbagai informasi dengan cepat dan akurat dapat disampaikan oleh surat kabar. Pembaca menjadi pembeli ataupun berlangganan surat kabar karena ingin mengetahui informasi apa yang terjadi di berbagai tempat di dunia.

b. Fungsi mendidik, surat kabar secara tidak langsung memberikan fungsi pendidikan pada pembacanya. Ini bisa dilihat dari materi isi seperti artikel, feature dan juga tajuk. Materi isi tersebut disamping memberikan informasi juga menambah perbendaharaan pengetahuan pembacanya walaupun bobot pemahaman tiap pembaca berbeda-beda.

c. Fungsi mempengaruhi, berita pada surat kabar secara tidak langsung mempengaruhi para pembacanya, sedangkan tajuk rencana dan artikel dapat memberikan pengaruh langsung kepada pembacanya. Pengaruh ini pada mulanya timbul dari persepsi pembaca terhadap suatu masalah yang kemudian membentuk opini pada pembacanya.

\section{HASIL DAN PEMBAHASAN}

Seperti diketahui, penyampaian aspirasi melalui media massa oleh masyarakat kepada pemerintahnya sudah cukup umum dilaksanakan. Namun, pengelolaan atas masukan, kritik, maupun keluhan publik tersebut berbeda-beda di masing-masing daerah. Efektivitas penanganannya pun berbeda-beda, padahal aspirasi masyarakat tersebut penting sebagai gambaran keberhasilan suatu penyelenggaraan pemerintahan. Jika aspirasi yang disampaikan banyak berisi apresiasi kepada pemerintah daerah tentu mencerminkan keberhasilan pelaksanaan pemerintahan, namun jika sebaliknya, berisi berbagai macam persoalan maka t e n t u m e n g i n d i k a s i k a n penyelenggaraan pemerintahan yang belum cukup baik.

Kolom atau rubrik penyampaian aspirasi publik kepada pemerintah daerahnya tersebut biasanya disediakan langsung oleh pemerintah daerah dengan bekerjasama dengan pihak surat kabar yang ada. Namun juga terkadang, kolom atau rubrik penyampaian aspirasi publik tersebut justru disediakan secara gratis oleh pihak surat kabar (contoh pada Tribun Pontianak) dalam rangka berperan sebagai penghubung komunikasi 
antara publik dengan pengambil kebijakan di daerah.Berangkat dari pemahaman tersebut, penulis mengasumsikan secara sederhana bahwa kolom atau rubrik pengaduan masyarakat tersebut sebagai wadah komunikasi antara publik dengan pemerintah daerah, sedangkan surat kabar berperan dalam hal publikasinya secara luas. ${ }^{2}$

Kalimantan Timur secara umum menerapkan dua model penanganan penyampaian aspirasi publik yaitu, pertama, dengan menampilkan seluruh saran, kritik, maupun apresiasi masyarakatnya secara langsung tanpa adanya tanggapan dari pemerintah daerahnya, dan kedua, dengan menampilkan aspirasi publik disertai jawaban atau penjelasan singkat dari pemerintah daerahnya. Pemerintah daerah di Kalimantan Timur secara umum cenderung menerapkan model pertama tersebut, sedangkan khusus Pemerintah Kabupaten Kutai Kartanegara menggunakan model yang kedua.

Tabel 1. Kolom Pengaduan Masyarakat Kota Balikpapan, Kabupaten Paser, Kota Bontang di Surat Kabar

\begin{tabular}{|c|c|c|}
\hline Kota Balikpapan & Kabupaten Paser & Kota Bontang \\
\hline 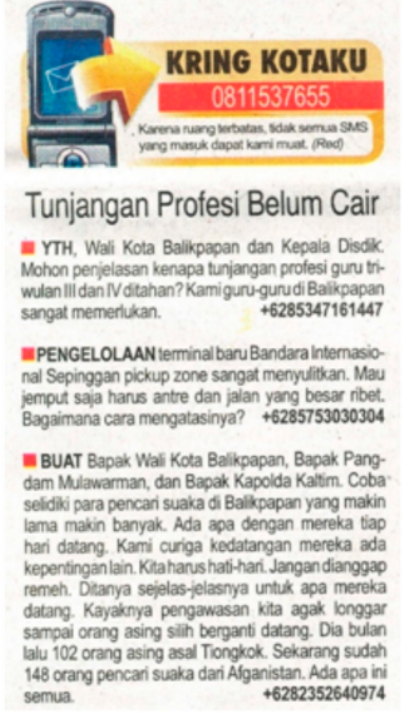 & 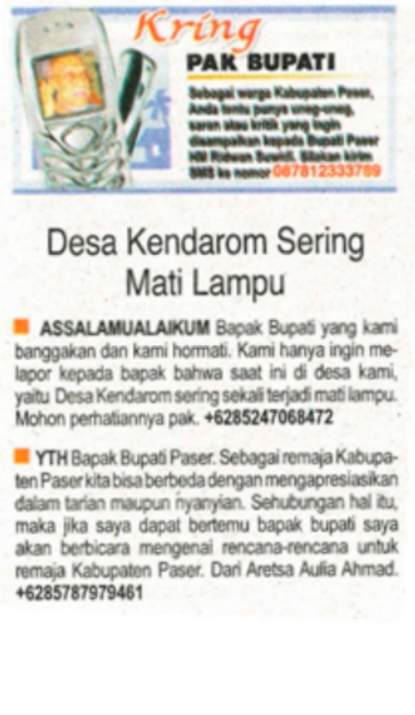 & 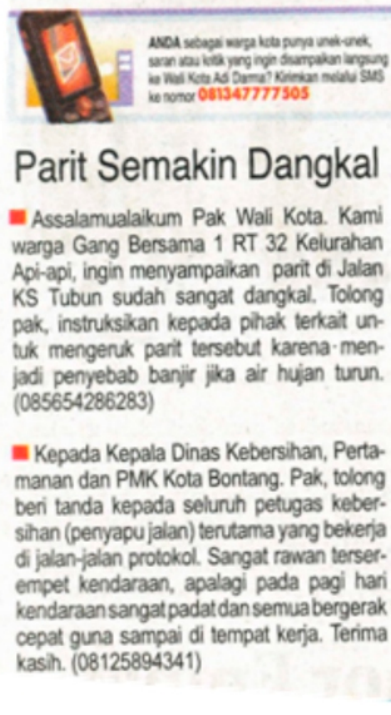 \\
\hline Sumber : Kaltim Post, 11 Desember 2014 & Sumber : Kaltim Post, 11 Desember 2014 & Sumber : Kaltim Post, 19 Januari 2015 \\
\hline
\end{tabular}

2 Asumsi ini dibangun untuk mempersempit atau menyederhanakan ruang lingkup pembahasan 
Dari kolom aspirasi publik yang diberlakukan pada Kota Balikpapan, Kabupaten Paser, dan Kota Bontang memiliki kesamaan/ mirip. Warga masyarakat masingmasing daerah tersebut memberikan aspirasinya kepada pemerintah daerahnya melalui SMS yang dikirimkan ke nomor yang telah disediakan dan selanjutnya dipublikasikan di surat kabar. Namun demikian, seluruh aspirasi publik tersebut terkesan hanya sekedar ditampilkan saja, atau dengan kata lain masih bersifat satu arah/ monoton yaitu dari publik kepada pemerintah daerahnya. Kondisi ini menjadikan posisi pemerintah daerah terkesan pasif. Kesan yang timbul kemudian adalah publik hanya menyampaikan "uneg-uneg"nya tanpa ada tanggapan jelas dan tertulis atau kemungkinan tindaklanjut dari pemerintah daerahnya. Kondisi ini tentu kurang efektif dan perlu dibenahi karena dapat menyebabkan publik merasa tidak diperhatikan, dan relatif berpotensi pada timbulnya sikap apatis publik kepada pemerintah daerahnya. Bahkan terkadang timbulnya protes warga dalam bentuk demonstrasi relatif juga dapat diindikasikan sebagai wujud ketidakperhatian pemerintah atas aspirasi yang disampaikan tersebut.

Meskipun tidak terdapat informasi yang akurat apakah aspirasi publik tersebut ditindaklanjuti oleh pemerintah daerahnya atau tidak, namun dengan tidak adanya tanggapan jelas, tertulis, dan terpublikasikan dari pemerintah daerah, relatif menimbulkan pertanyaan umum apakah aspirasi publik tersebut 'minimal' dibaca. Tingginya respon warga masyarakat untuk menyampaikan masukan kepada pemerintah daerah tentu perlu dihargai dan dapat ditandai sebagai bentuk dukungan kepada pemerintah daerah agar dapat bekerja lebih baik dalam mensejahterakan warganya dan menghadirkan pelayanan publik yang lebih baik. Oleh karena itu, sebagai wujud responsivitas yang tinggi serta transparasi publik, sebaiknya pemerintah daerah dapat memberikan tanggapan kepada publik atas setiap aspirasi publik yang masuk. Adanya penjelasan dari pemerintah daerah juga merupakan wujud pembelajaran dan upaya sosialisasi secara jelas kepada publik, sebab terkadang publik tidak mengetahui secara jelas batasan kewenangan pemerintah daerah dan kewenangan pemerintah pusat, ataupun keterbatasan lain yang dihadapi oleh pemerintah daerahnya.

Hal ini sebagaimana disampaikan oleh Dwiyanto (2011:379) bahwa sumberdaya yang dimiliki pemerintah terbatas sementara pemerintah dihadapkan pada kepentingan warga yang semakin beraneka ragam dan harus dipenuhi. Kondisi demikian 
membuat kapasitas dan kompetensi pemerintah untuk memenuhi kebutuhan warga semakin jauh dari harapan warga. Administrator harus dapat mengelola ekspektasi warga terhadap pemerintah secara baik karena peningkatan kapasitas dan kompetensi pemerintah untuk memenuhi kebutuhan pelayanan yang semakin kompleks tidak dapat dilakukan secara cepat.

Kondisi yang berbeda ditampilkan oleh Pemerinta Kabupatan Kutai Kartanegar d a la m k olom a s piras publiknya.Model penangana1 aspirasi publik yang diberlakuka1 adalah dengan tidak hany: menampilkan pengaduan ataı aspirasi masyarakat semata, namur juga memberikan jawaban atas setiap aspirasi yang disampaikan Namun demikian, mode] penanganan seperti ini tentu berimplikasi pada kuantitas aspirasi publik yang dapat ditampilkan tidak lebih banyak atau lebih sedikit dibandingkan model penanganan kolom aspirasi publik yang diberlakukan pada Kota Balikpapan, Kabupaten Paser, dan Kota Bontang yang secara kuantitas dapat menampilkan lebih banyak aspirasi publik.

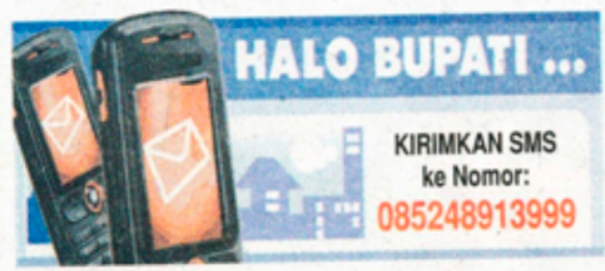

\section{Toiletnya Jorok}

KEPADA Ibu Kepala SD 005 dekat Taman Ulin, tolong perhatikan toilet umum. Kondisinya kotor dan pintunya rusak. Terima kasih. $\quad$ 08525093XXXX

Jawab:

Kepala sekolah agar memerhatikan kondisi tersebut.

- MOHON perhatan terhadap nasib karyawan dince processingunit (RPU), karenamerupakan aset daerah. Sampai saat ini, RPU masih produksi. Tetapi tidak ada kejelasan soal nasib karyawannya. Sudah 10 bulan tidak digaji.

08222083XXXX

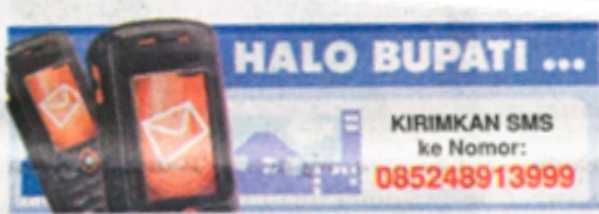

\section{Tegur Kontraktor Jalan}

- YTH Ibu Bupati Kukar, bukan kita tidak mendukung pembangunan, tapi tolong ditegur kontraktor yang mengerjakan jalan jalur Tenggarong-Kota Bangun tepatnya di KM 19, kendaraan bisa antre sampai satu jam karena kontraktor tidak tahu aturan. 08525021 XXXXX

\section{JAWAB:}

Untuk kelancaran semua, informasi Anda akan disampaikan pada instànsi terkait untuk monitor kelancaran pekerjaan lalu lintas di lokasi tersebut.

- YTH kepada pengurus Korpri Kukar dan pengembang perumahan Korpri Tenggarong Seberang, kiranya bisa melihat titik-titik longsor yang bisa meruntuhkan beberapa perumahan khususnya di Blok F1 dan F2. Banyak jurang terjal, sekian terima kasih. $\quad 08525094 \times$ XXXX

\section{JAWAB:}

Informasi Anda akan disampaikan kepada pengembang melalui KORPRI Kab Kukar.

\section{(Sumber : Kaltim Post, 2014)}

Gambar 1. Sarana Pengaduan Masyarakat Kabupaten Kutai Kartanegara di Media Massa 
Kolom Halo Bupati yang dikembangkan oleh Pemerintah Kabupaten Kutai Kartanegara relatif cukup baik dan responsif karena aspirasi yang disampaikan masyarakat langsung disertai dengan tanggapan atau jawaban, meskipun realisasi atas jawaban yang diberikan pemerintah daerah tersebut dilaksanakan atau tidak, namun setidaknya publik mengetahui bahwa aspirasi mereka telah dibaca. Pada kolom ini, posisi pemerintah daerah cukup aktif meskipun jawaban atau tanggapan yang diberikan lebih atau masih bersifat penyampaian informasi saja ke SKPD yang terkait. Dalam hal ini kekuatan jawaban atau responnya relatif masih kurang jika dibandingkan model rubrik Kota Pontianak (Gambar 2) dan Kalimantan Selatan (Gambar 3) yang memberikan penjelasan yang lengkap serta langkah tindaklanjutnya.

Kondisi ini mungkin terjadi dikarenakan pengelolaan keluhan, kritik, dan saran publik tersebut dilakukan oleh suatu unit pengaduan masyarakat (complaint center) yang secara umum bertugas untuk menerima aspirasi masyarakat kemudian meneruskannya kepada SKPD yang terkait untuk ditindaklanjuti.Untuk optimalisasi fungsi kolom aspirasi publik tersebut sebaiknyacomplaint centerKabupaten Kutai Kartanegara selain meneruskan SMS pengaduan publik kepada SKPD terkait, juga sekaligus dapat meminta jawaban dari SKPD terkait sehingga penjelasan yang dapat disampaikan atau dipublikasikan pada surat kabar dapat lebih lengkap dan memuaskan. Selain itu, seluruh masukan publik beserta respon yang diberikan perlu dilaporkan kepada Kepala Daerah sehingga dapat dilakukan kontrol terhadap realisasi langkah tindak lanjut SKPD terkait atas pengaduan yang ada.

Berbeda pula mekanisme pemanfaatan kolom aspirasi publik di Kota Pontianak yang diberi nama Rubrik Yok Bangon Kote Kite yang sudah diluncurkan sejak Tahun 2010 dan dikategorikan cukup berhasil karena telah memotivasi warga Kota Pontianak untuk berpartisipasi aktif di semua sektor pembangunan. Rubrik ini juga berhasil meredam masyarakat yang menyampaikan aspirasinya dengan cara demonstrasi. Rubrik Yok Bangon Kote Kite ini juga menjadi media bagi walikota untuk melihat sejauh mana kinerja SKPD yang ada terhadap tugas dan tanggung jawabnya. Manfaat lain dari rubrik ini adalah media bagi pejabat untuk mengetahui tugas pokok dan fungsi serta permasalahan di SKPD lainnya. Sehingga jika terdapat mutasi, yang bersangkutan minimal sudah mengetahui apa permasalahan SKPD tersebut, sehingga tidak perlu belajar dari awal lagi. (Ashari, 2013:5)

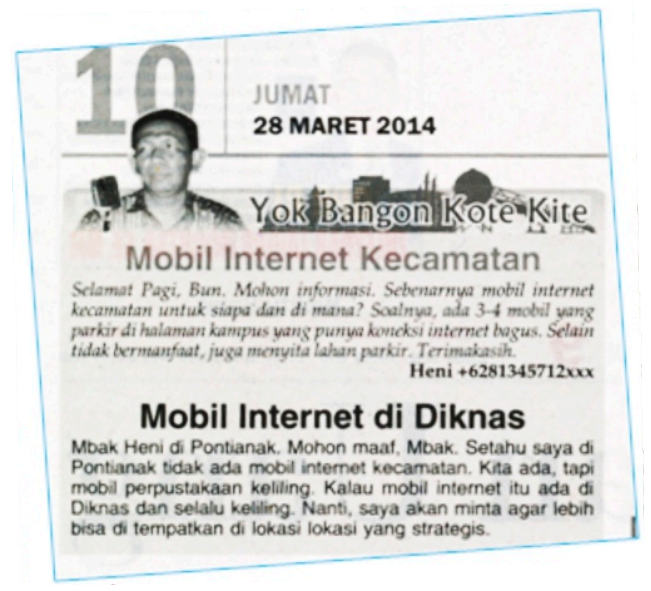




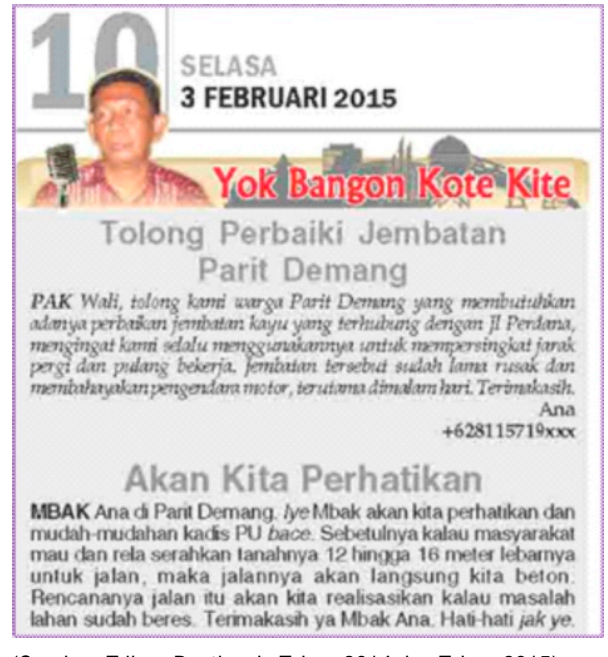

(Sumber: Tribun Pontianak, Tahun 2014 dan Tahun 2015)

Gambar 2. Interaksi Publik dengan Pemerintah Kota Pontianak di Media Massa

Jika dianalisis, model rubrik yang dijalankan Pemerintah Kota Pontianak lebih bersifat interaktif karena memberikan penjelasan secara jelas serta rencana tindak lanjut atas aspirasi yang disampaikan secara lebih komprehensif. Bahkan, seluruh solusi atau jalan keluar yang disampaikan secara jelas terlihat merupakan instruksi langsung kepada SKPD yang terkait untuk menindaklanjutinya. Kondisi ini terjadi dikarenakan kepala daerahnya sendiri, yaitu Walikota Pontianak, yang langsung memberikan jawaban atas setiap aspirasi publik yang masuk, dan jawaban tersebut merupakan perintah yang harus segera direspon oleh SKPD yang terkait.

Ide awal pembuatan rubrik ini ternyata berasal dari media massa sendiri yaitu Tribun Pontianak yang ingin mewadahi keinginan publik dan kebijakan Pemerintah Kota, kemudian direspon oleh Walikota Pontianak, Sutarmidji untuk bekerjasama merealisasikan rubrik tersebut, bahkan Pemerintah Kota tidak mengeluarkan biaya untuk pembuatan dan pengelolaan rubrik tersebut (Ashari, 2013 : 1).Di sisi lain, tidak jarang SMS pengaduan yang dikirimkan warganyamenjadi bahan bagi pemerintah untuk menyusun kebijakan dan program-program pembangunan yang lebih pro-rakyat dan tepat sasaran. Bahkan sangat membantu Kepala Daerah, karena banyak pertanyaanpertanyaan yang menginspirasi dalam upaya melakukan percepatanpercepatan dalam pembangunan Pontianak (Ashari, $2013: 2-5$ )

Penggunaan judul rubrik "Yok Bangon Kote Kite" juga relatif lebih baik karena terkesan bahwa Pemerintah Kota Pontianak memerlukan publik dan mengajak partisipasi publik Kota Pontianak bagi kemajuan daerah secara bersamasama. Berbeda dengan judul kolom/ rubrik yang digunakan pada Kota Balikpapan yang menggunakan tema/ judul "Kring Kotaku", Kabupaten Paser dengan tema/ judul "Kring Pak Bupati" (Tabel 1), dan Kabupaten Kutai Kartanegara dengan tema/ judul "Halo Bupati" (Gambar 1) yang relatif terkesan bahwa hanya publik yang memiliki kesadaran untuk perbaikan/ kemajuan daerah. Meskipun esensi interaksi publik tidak ditunjukkan dengan nama atau judul rubrik semata, namun setidaknya dari nama atau judul rubrik tersebut sudah menunjukkan posisi pemerintah daerah yang seharusnya sejajar dengan publiknya dan saling membutuhkan.

Model penyampaian aspirasi publik di Kalimantan Selatan juga menunjukkan format yang berbeda, namun dari segi esensi penanganannya 
relatif sama dengan Kota Pontianak. Aspirasi publik yang masuk langsung ditanggapi oleh pihak atau instansi yang terkait secara lugas, sehingga publik dapat memahami dan memperoleh kejelasan atas aspirasi yang disampaikan.Rubrik pengaduan publik pada harian Banjarmasin Post ini ditayangkan pada halaman khusus yang memuat pengaduan masyarakat untuk Pemerintah Daerah atau instansi yang terkait.

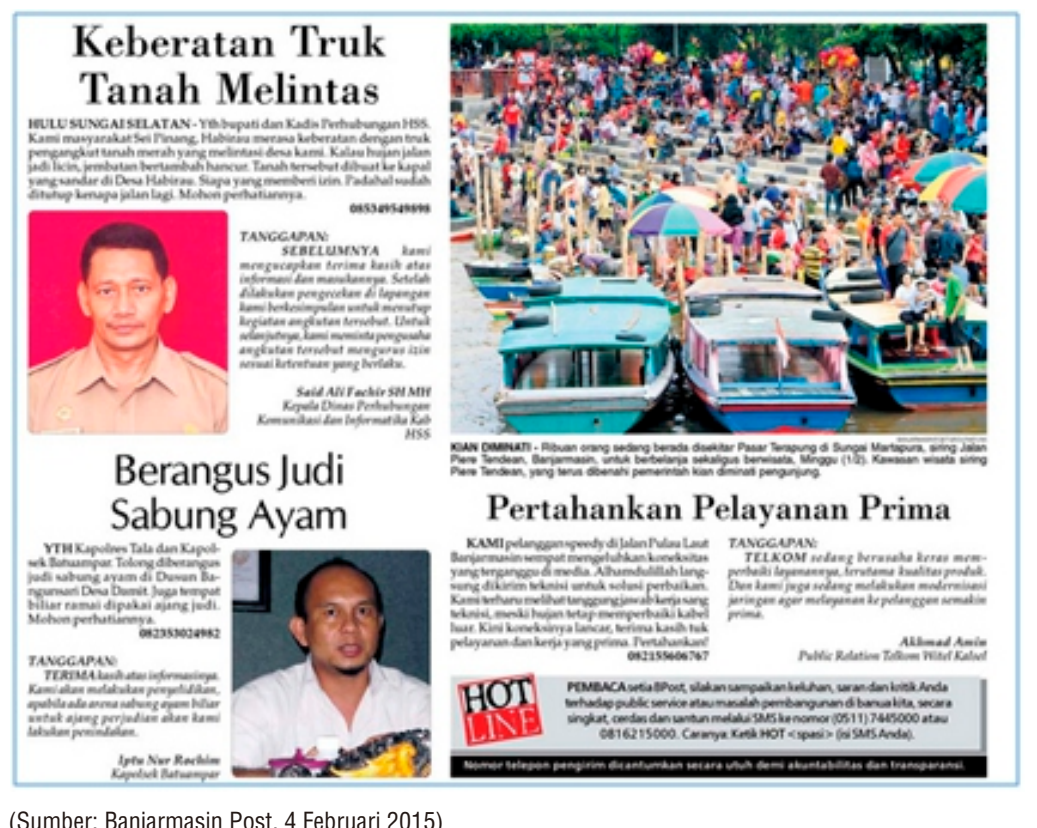

Gambar 3. Interaksi Publik dengan Pemerintah Daerah di Kalimantan Selatan

Pada kolom aspirasi publik di Kalimantan Selatan tersebut terlihat bahwa pelimpahan kewenangan untuk menjawab pertanyaan-pertanyaan teknis dari masyarakat telah diberikan kepada pejabat teknis yang terkait. Dengan demikian, secara lengkap dapat dijelaskan dan direspon oleh pelaksana teknis di lapangan. Model penganan pengaduan publik ini juga cukup baik setidaknya pada dua sisi, yaitu sisi publik, karena publik dapat mengetahui siapa yang merespon atau memberikan tanggapan, dan dapat meminta kejelasan atas realisasi yang disampaikan. Dari sisi pemerintah daerah, khususnya kepala daerah tinggal memantau pelaksanaan dan melakukan penilaian atas respon yang diberikan pihak atau instansi yang terkait. Ketika hubungan antara pemerintah dan warganya semakin interaktif serta partisipatif, warga akan semakin familiar dengan kegiatan pemerintahan. Semakin intensifnya hubungan antara warga dan pemerintah dapat menjadikan warga memiliki emotional attachment dengan pemerintah dan kebijakannya (Dwiyanto, 2011:366)

Membangun sebuah pelayanan yang berkualitas memang bukanlah hal 
yang mudah, karena akan ditemui beberapa tantangan dan kendala yang seharusnya disikapi secara positif. Tantangan dan kendala ini wajar terjadi mengingat banyaknya komponen penunjang pengelolaan pelayanan publik, belum lagi sifat dan karakter masyarakat yang dilayani sangat beragam. Upaya peningkatan kualitas pelayanan publik harus terus dilakukan mengingat kondisi pelayanan publik saat ini masih jauh dari yang diharapkan (PKP2A III LAN, 2013:20)

Keseluruhan model penanganan pengaduan publik yang telah dijelaskan di atas dapat dihimpun suatu penjelasan bahwa pengelolaan kolom aspirasi atau pengaduan publik adalah suatu hal yang penting dalam menunjang pelayanan publik yang optimal. Banyak informasi yang diluar jangkauan pemerintah dapat diketahui berkat masukan publik tersebut, bahkan dapat dikatakan bahwa kolom aspirasi publik di surat kabar adalah bentuk lain dari 'blusukan', yang memiliki kemiripan karena sama-sama mendengarkan dan menampung aspirasi publik. Hanya saja pengelolaan terhadap aspirasi publik tersebut perlu dioptimalkan dengan memberikan penjelasan, tanggapan, jawaban, dan respon yang cepat, jelas, dan tingkat eksekusinya tinggi di lapangan. Pada akhirnya, publik merasa dihargai dan dapat merasakan kehadiran dan kepedulian pemerintah.Dengan strategi komunikasi yang tepat dan efektif, persepsi yang positif terhadap kinerja pemerintah dapat dibentuk (Dwiyanto, 2011:365)

\section{E. PENUTUP \\ Kesimpulan}

Meningkatkan kepercayaan masyarakat kepada pemerintah daerahnya dapat dicapai dengan menghadirkan pemerintah ditengah masyarakat, salah satu caranya adalah dengan menerima aspirasi publik kemudian meresponnya dengan cepat dan tepat. Berbagai langkah dilakukan untuk merealisasikan ini diantaranya penyediaan media pengaduan publik di berbagai media massa. Masyarakat tentu menghendaki kinerja pemerintahnya berjalan baik serta pelayanan publik yang semakin berkualitas, sehingga membuat mereka secara aktif memberikan masukan, kritik, maupun apresiasi kepada pemerintahnya melalui media-media penyaluran aspirasi yang disediakan. Men-PAN RB, Yuddy Chrisnandi (2014) menegaskan bahwa pada dasarnya semakin banyak pengaduan semakin baik, dan yang terpenting adalah direspon dengan cepat. Karena itu akses masyarakat untuk mengadu harus diperluas. Dengan adanya pengaduan, dapat dilakukan peningkatan kualitas pelayanan publik, bahkan pemerintah daerahbisa melakukan inovasi.

Dari berbagai model penanganan pengaduan masyarakat yang diperlihatkan pada surat kabar lokal di Kalimantan, secara umum dapat diberikan penilaian bahwa model penanganan kolom aspirasi publik yang lebih interaktif, dua arah, komunikatif, dan disertai langkah tindak lanjut adalah model penanganan yang lebih baik. Hal ini tentu menunjukkan kemampuan inovasi pemerintah daerah dalam memanfaatkan kesempatan berkomunikasi dengan publik. Dari contoh yang ada, kolom aspirasi publik yang dijalankan oleh Kota Pontianak di 
harian Tribun Pontianak, dan Kalimantan Selatan di Harian Banjarmasin Post adalah contoh terbaik yang menunjukkan kehadiran pemerintah ditengah masyarakat. Selanjutnya, salah satu ukuran kesuksesan pemerintah daerah dari keberadaan kolom aspirasi publik tersebut adalah ketika aspirasi yang disampaikan oleh publik hanya berisi apresiasi atau kepuasan kepada kinerja pemerintah daerahnya.

\section{Rekomendasi}

Pemerintah daerah perlu bekerjasama secara aktif dengan pers (media massa) dalam mendorong peningkatan kepercayaan publik melalui penyediaan kolom aspirasi publik yang interaktif dan komunikatif sebab, keterbukaan (transparansi) pemerintah daerah serta kedekatan pemerintah daerah dengan warganya dapat diukur dari kemudahan publik untuk berkomunikasi dengan pemerintahnya. Disisi lain, publik juga perlu didorong dan ditempatkan sebagai 'mata-mata' pemerintah daerah untuk selalu memberikan informasi kepada pemerintah daerah mengenai kondisi lingkungannya secara valid dan nyata. Jika hal ini dapat dikelola dengan baik, pemerintah daerah memiliki sumber masukan/input untuk membenahi hasil kinerja pemerintahannya.

Dalam hal pengelola pengaduan adalah sebuah tim atau complaint center, maka memberikan pelatihan kepada pengelola pengaduan penting dilakukankarena teknik komunikasi dengan publik memerlukan keahlian khusus agar publik dapat memahami penjelasan pemerintah daerah yang disampaikan secara terang dan lengkap.

\section{F. DAFTAR PUSTAKA}

Ashari, Hasyim. (2013). SMS Mengubah Pontianak : Interaksi Walikota Sutarmidji Dengan Warganya. TOP Indonesia: Pontianak

Bappenas (2010). Manajemen Pengaduan Masyarakat dalam Pelayanan Publik. Direktorat A p a r a u $\mathrm{N}$ e g a r a . Kementerian Perencanaan Pembangunan Nasional. Jakarta

Dwiyanto, Agus. (2011). Mengembalikan Kepercayaan Publik Melalui Reformasi Birokrasi. Gadjah Mada University Press. Yogyakarta

Kurniawan, Eko. (2006). Studi Analisis Isi Pemberitaan Media Massa Tentang Lingkungan Hidup dan Implikasinya Terhadap Kebijakan Pengelolaan Lingkungan di Kabupaten Bangka. Program Magister Ilmu Lingkungan. Program Pascasarjana Universitas Diponegoro: Semarang

Lal Das, D.K and Bhaskaran, V (eds.). (2008) Research methods for Social Work, N e w Delhi:Rawat, $p p .173-193$.

LAN. (2006). Strategi Peningkatan Kualitas Pelayanan Publik. LAN:Jakarta

Livingstone, Sonia and Markham, Tim (2008).The Contribution of Media Consumption to Civic Participation. British Journal of Sociology, 59 (2). pp. 351371

Nuh, Mohammad. (2010). Dialektika Kebijakan dan Kinerja Governance: Sebuah Kajian Teoritis. Bagian dari Buku 
Reformasi Aparatur Negara Ditinjau Kembali. Diterbitkan bersama oleh Penerbit Gava Media dan Jurusan Manajemen dan Kebijakan Publik dan Magister Administrasi Publik: Yogyakarta

PKP2A I LAN. (2008). Perumusan Kebijakan Penetapan Indeks Pelayanan Publik Bagi Kecamatan. PKP2A I LAN: Bandung

PKP2A III LAN. (2013). Inovasi Pelayanan Publik di Wilayah Kalimantan. PKP2A III LAN: Samarinda

Purwanto, Eko Agus (2008). Pelayanan Publik Partisipatif. Kumpulan tulis an dalam buk u Mewujudkan Good Governance Melalui Pelayanan Publik. Agus Dwiyanto (editor). Gadjah Mada University Press : Yogyakarta (173-222)

Santoso, Budi. (2014). Mayoritas Pengaduan ke Ombudsman Terkait Pemda. Available online at http://www. hukumonline.com/berita/baca /1t54924edb9ef32/mayoritaspengaduan-ke-ombudsmanterkait-pemda. Diakses tanggal Tanggal 26 Februari 2015
Setianti, Yanti., Hanny Hafiar, Nurmaya Prahatmaja. (2007). Analisis Isi Pemberitaan Tentang Kabupaten Garut. Fakultas Ilmu Komunikasi. Universitas Padjadjaran: Bandung

Taleghani, Mohammad, Mahmood Samadi Largani, Shahram Gilaninia, Seyyed Javad Mousavian. (2011). The Role of Customer Complaints Management in Consumers Satisfaction for New Industrial Enterprises of Iran. International Journal of Business Administration. Vol. 2, No. 3; August 2011

Wah, Tam Weng. (2011). Public Complaints As Source of Innovation for Government A g e n i es. Journal EXCELLENCE. Volume 3, Number 1-2011

Yuddy Chrisnandi. (2014). Pemerintah Dorong Masyarakat Berani Mengadu. Available on http://www.menpan.go.id/beri ta-terkini/2777-pemerintahdorong-masyarakat-beranimengadu. Diakses Tanggal 26 Februari 2015 